\title{
First record of Craspedacusta sowerbii Lankester, 1880 (Hydrozoa, Limnomedusae) in a natural freshwater lagoon of Uruguay, with notes on polyp stage in captivity
}

\author{
M. G. Failla Siquier ${ }^{*}$, W. S. Serra Alanis ${ }^{a}$ and C. Martinez Debat ${ }^{b}$ \\ ${ }^{a}$ Departamento de Biología Animal, Facultad de Ciencias, Universidad de la República - UdelaR, \\ Iguá, 4225, 11400, Montevideo, Uruguay \\ 'Sección Bioquímica, Departamento de Biología Celular y Molecular, Facultad de Ciencias, \\ Universidad de la República - UdelaR, Iguá, 4225, 11400, Montevideo, Uruguay \\ *e-mail: gabrielafailla@gmail.com
}

Received: July 30, 2015 - Accepted: May 25, 2016 - Distributed: November 31, 2017

(With 5 Figures)

\begin{abstract}
The freshwater cnidarian Craspedacusta sowerbii Lankester 1880, has invaded lakes and ponds as well as artificial water bodies throughout the world. The first record in Uruguay corresponding to the jellyfish was made in 1961 in two artificial fountains, with no mention of the polyp form. Although local reports of other related polyp species have been made, information on the benthic form of $C$. sowerbii is lacking. Here we report the finding of live frustules, solitary individuals, medusae and colonies from a natural lagoon in August 2010, allowing us to observe the morphology and behavior of the polyp stage in captivity. In addition, molecular identification and remarks on the potencial path of introduction are presented. This is the first record in Uruguay of both polyp and medusa stages of C. sowerbii in a natural water body, Del Medio Lagoon (Dpto. de Florida), Uruguay.
\end{abstract}

Keywords: Craspedacusta sowerbii, freshwater jellyfish, 16S RNA, polyp stage, Uruguay.

\section{Primeiro registro de Craspedacusta sowerbii Lankester, 1880 (Hydrozoa, Limnomedusae) em uma lagoa natural de água doce do Uruguai, com observações da fase de pólipo em cativeiro}

\begin{abstract}
Resumo
O cnidário Craspedacusta sowerbii Lankester 1880 de água doce, tem invadido lagos e lagoas, bem como corpos de água artificiais em todo o mundo. O primeiro registro no Uruguai correspondente à água-viva foi feita em 1961, em duas fontes artificiais, sem mencionar a forma de pólipo. Embora existem relatórios locais de pólipos de outras espécies relacionados, informações sobre a forma bentônica de $C$. sowerbii ainda são escassas. Neste trabalho se relata a ocorrência de frústulas vivas, de indivíduos solitários, medusas e colônias de uma lagoa natural, em agosto de 2010, onde foi possível observar a morfologia e comportamento da fase de pólipo em cativeiro. Além disso, identificação molecular e observações sobre a potencial via de entrada da espécies são apresentados. Este é o primeiro registro no Uruguai de ambos estágios de vida de C. sowerbii em um corpo de água natural, Lagoa Del Medio (Dpto. De Florida), Uruguai.
\end{abstract}

Palavras-chave: Craspedacusta sowerbii, medusa de água doce, 16S RNA, fase de pólipo, Uruguai.

\section{Introduction}

Craspedacusta sowerbii Lankester 1880, is distributed worldwide with the exception of Antarctica, and is particularly common in subtropical to temperate regions. The species occurs in nearly all types of natural freshwater habitats, including ponds, rivers, lakes and streams, mainly in mesotrophic to eutrophic environments (Jankowski et al., 2008). They have also been observed in artificial environments, e.g. gravel and clay pits, garden ponds, reservoirs, aquaria and fountains (Fritz et al., 2007). The species C. sowerbii was described by Lankester (1880) from specimens collected in water-lily tanks at Regents Park of London in 1880 and later a polyp discovered in the same tank was correctly assumed to be a form of $C$. sowerbyi (Payne, 1924). Similar polyps were found in Philadelphia and described as a separate species, Microhydra ryderi, Potts 1885. Boulenger and Flower (1928) later clarified that $M$. ryderi was the polyp form of $C$. sowerbyi.

Although some controversy does exist, it was shown in the 1950s that the species originated from the Yangtze-kiang River Basin in China, with up to four endemic species 
of the same genus (Dumont, 1994; Jankowski, 2001). The possession of several asexual reproductive and resting forms, such as a budding polyp, mobile frustules or podocysts allows it dispersion via co-transportation of resting stages with plants, fish and humans (Dumont, 1994), which in turn results in log-term survival without sexual reproduction (Fritz et al., 2007).

Records of C.sowerbii in South American date back to the 1930s, with some recent observations and sightings in Brazil, Argentina, Chile and Venezuela (Silva and Roche, 2007; Figueroa and de los Ríos, 2008; Savaris et al., 2013). The first report in Uruguay corresponding to the jellyfish was made by Mañé-Garzón and Carbonell (1971) in two artificial fountains in Artigas and Durazno (departments in northwest and central Uruguay, respectively), with no mention of the polyp stage. Although the polyp may be far more common than the medusa itself, it is more rarely seen than the adult stage (Dumont, 1994). The only local records of freshwater polyps in the country correspond to Cordilophora caspia (Pallas) (Cordero, 1941), in Las Brujas stream near the capital city of Montevideo and to a hydranth of Calpasoma dactylopterum Fuhrmann 1939, casually mentioned by Dioni (1974) as occurring in an artificial pond in Montevideo without further detail. In January 2010 in the Del Medio Lagoon (Florida-Uruguay), the first bloom of C. sowerbii was sighted by Failla Siquier and Serra Alanis (Pers. obs.). Local bathers had previously noticed the presence of "jelly organisms" in consecutive summers of 2008 and 2009, which caused surprise and caution but had no further implications and thus the event went unreported by local authorities. Then, in summers of 2011 and 2012 two jellyfish blooms events have been recorded and individuals were sampled by the authors without the detection of the polyp stage. The present finding represents the first record in a natural water body of both stages, polyp and medusa, of $C$. sowerbii in a new locality, Del Medio Lagoon (Dpto. de Florida), Uruguay. In addition, the species identification is confirmed by molecular methods and some remarks on the morphology and behavior of the polyp stage in captivity are presented.

\section{Material and Methods}

Site description: Del Medio Lagoon is located in the upper basin of the Santa Lucía River, in the department of Florida, Uruguay (Figure 1). It is a marginal lagoon of $375 \mathrm{~m}$ in maximum length and $40 \mathrm{~m}$ in maximum width, reaching a maximum depth of about $5 \mathrm{~m}$. The lagoon is protected from wind by surrounding trees and in summertime tourism is a prominent activity. Tributaries are present and water supply is mainly influenced by rainfall and river input.
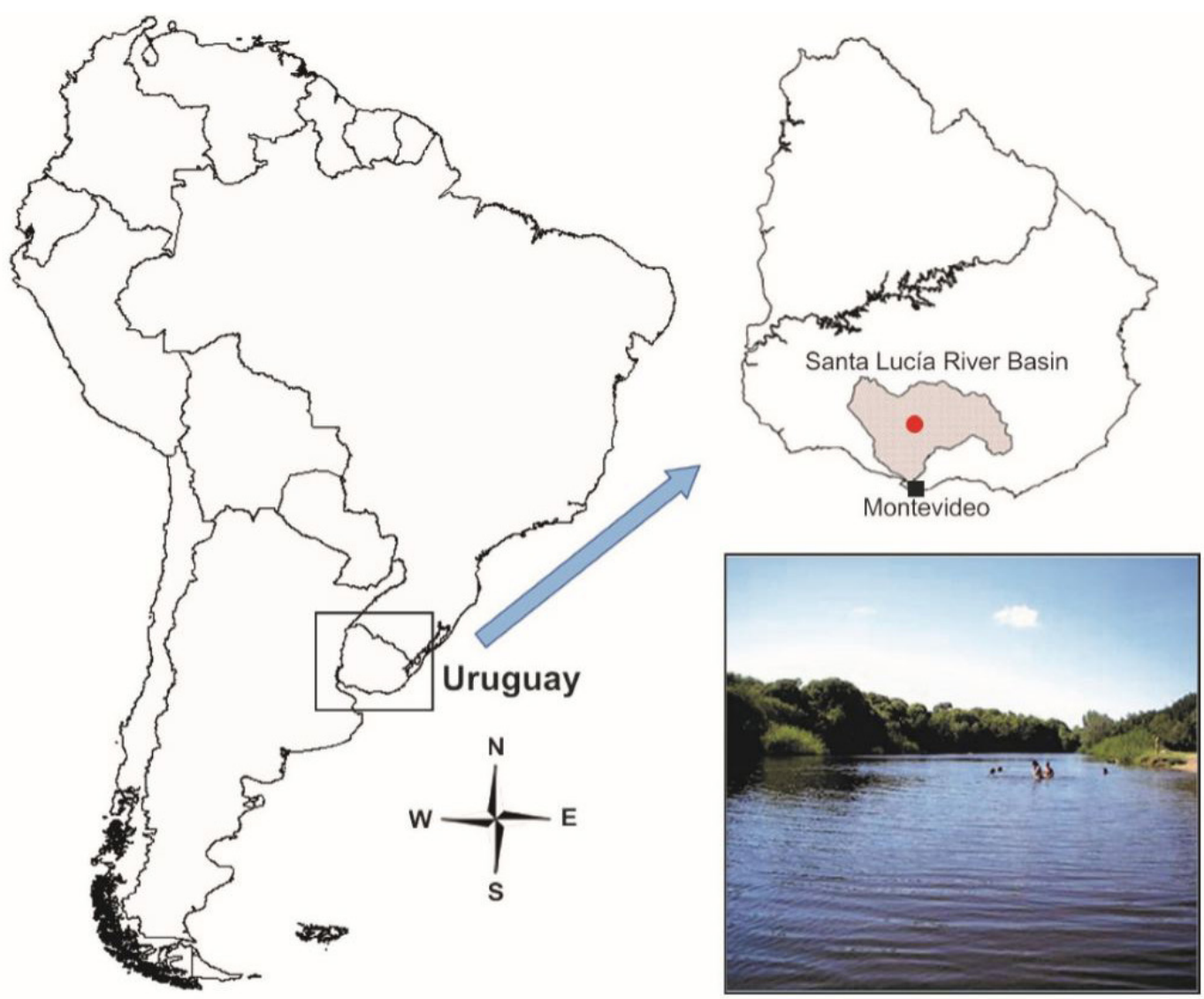

Figure 1. Location of the Santa Lucía basin in Uruguay (gray) and the Del Medio Lagoon (round spot). The photograph shows the recreation area of the Lagoon. 
Between january $15^{\text {th }}$ and $30^{\text {th }} 2010$ a bloom of $C$. sowerbii have been recorded and samples were collected manually with a $650 \mu$ mesh sieve. Some jellyfish were preserved with $70 \%$ ethanol and those used for DNA extraction and analysis were stored at $-80^{\circ} \mathrm{C}$. DNAeasy Blood \& Tissue Kit (Qiagen) was used to isolate the DNA, following the manufacturer instructions. DNA integrity was analyzed by agarose electrophoresis and its concentration measured in a Nanodrop device. A suitable dilution (100 ng) was amplified by PCR using $16 \mathrm{~S}$ primers, according to Cunningham and Buss (1993). Automatic sequencing was performed on the obtained amplicons with forward primer, and the results were edited by eye in Chromas Lite software, and analyzed by nucleotide blast algorithm (Altschul et al., 1990) on the database nucleotide collection ( $\mathrm{nr} / \mathrm{nt})$. The obtained DNA sequence has been published in Genbank, with Accession Number KX267739.

Twenty four specimes were maintained alive in an aquarium but died after a few days; however, water was kept aerated and at a constant level for several months by adding water from the lagoon. Samples from the bottom of the aquarium, branches of Egeria sp., and bivalve shells were periodically analyzed in search of polyps. On August $13^{\text {th }}$ of 2010 colonies and solitary polyps of C. sowerbii were found alive in the aquarium (at room temperature between $18-20^{\circ} \mathrm{C}$ ). One colony (a), solitary polyps and frustules were maintained alive in a Petri dish and kept in the refrigerator $\left(8^{\circ} \mathrm{C}\right)$ for further observation, while the other colony (b) was immediately preserved with 70\% ethanol. To identify the hydranths of these two colonies, individuals were named as " $a_{1-2}$ " and " $b_{1-2}$ ", respectively. The total length (TL) of each polyps was taken from the distal end of the capitulum to the base of the ramification point, and the total width (TW) was measured at the middle point between both ends. Solitary polyps were named as polyp 1 and polyp 2 . Solitary polyp and frustule measurements consisted of the distance between both ends (TL) and the width (TW) taken at the middle point. The basal attachment region (bar) corresponds to the teca-like basal portion. All measurements were made in micrometers. Taxonomic identification of C.sowerbii follows Jankowski (2001). Movements and behavior of both colonies and frustules were observed and recorded. Micrographs and videos were taken with a Sony Cyber-shot 6.0 DSC-S600 digital camera attached to an Olympus BX-50 microscope. Drawings were made "in vivo" and "in toto" with the aid of a camera lucida and microscope details were added free-hand. Polyps were deposited in the Collection of the Laboratorio de Zoología de Invertebrados, Facultad de Ciencias, Montevideo, Uruguay as AP/11169-11171.

\section{Results}

Two colonies of two individuals each, two solitary polyps and two frustules were recovered alive from the bottom of the aquarium. In addition two frustules were seen "in vivo" budding off from a hydranth. After these findings, careful inspection of the plants (Egeria sp.) and bivalves (Diplon sp.) remaining in the aquaria failed to reveal additional C. sowerbii individuals at the polyp stage.

\subsection{DNA analysis}

The expected $611 \mathrm{bp}$ fragment was obtained by PCR assays, and the automatic sequencing with forward primer yielded a 330 nucleotides long good quality sequence. After blast analysis the amplified DNA sequence (Genbank Accession Number KX267739) was found to be identical (100\% identity) to Craspedacusta sowerbii $16 \mathrm{~S}$ ribosomal RNA gene, GenBank Accession Number EU293971.1

\subsection{Description of polyps and frustules}

The live colony (Figures 2A and 3A), consisted of two similar hydroids (" $\mathrm{a}_{1}$ " and " $\mathrm{a}_{2}$ "), a distinct sclerotized orange-yellowish region and a basal attachment portion. The free distal end of each hydroid, without tentacles, with numerous nematocysts surroundig the mouth (hypostome) forming a spherical capitulum. Hydroids more or less transparent, such that the mouth opening detected only during the feeding process and the gastrovascular cavity observed by transparency. Nematocysts also scattered along all the hydranth's surface. Frustule budding in the upper end of the $\left(a_{1}\right)$ hydranth below the capitulum (Figure 2B). At rest hydranths cylindrical-like, narrowing at the base.

The preserved colony (Figure 2B) also consisted of two hydroids: a large polyp $\left(b_{1}\right)$, and a smaller polyp $\left(b_{2}\right)$ firmly joined to the former just above a small tiny differentiated

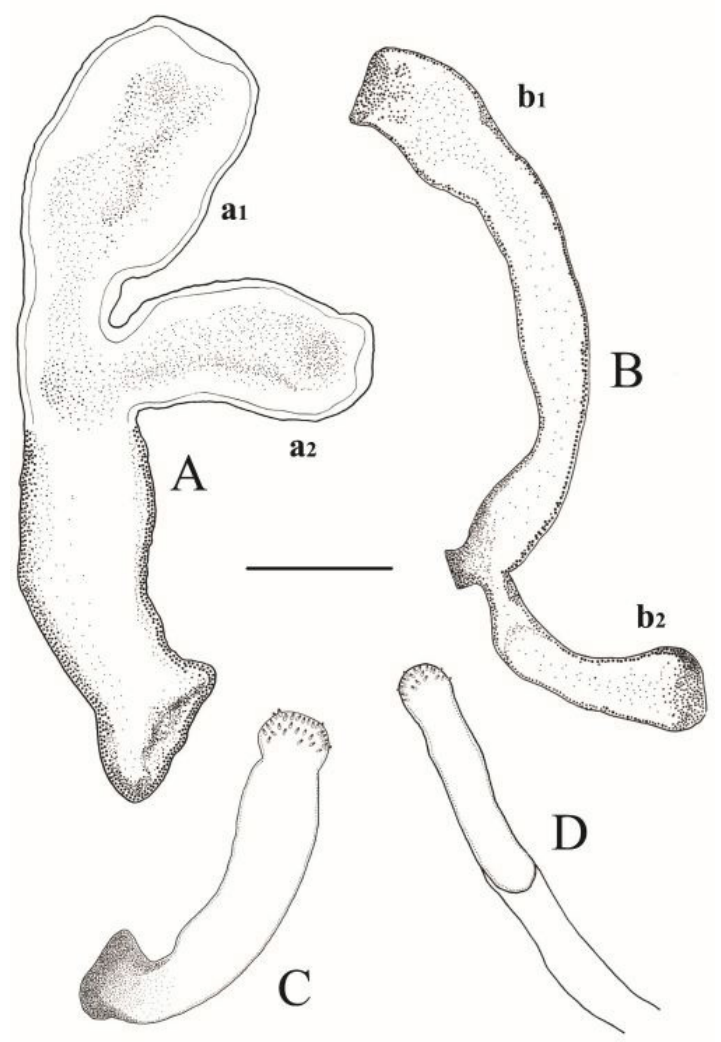

Figure 2. Craspedacusta sowerbii colonies and solitary polyps. (A) Colony (live) with two hydranths $\left(\mathrm{a}_{1}-\mathrm{a}_{2}\right)$; (B) Colony (preserved) with two hydranths $\left(\mathrm{b}_{1}-\mathrm{b}_{2}\right)$; (C) Solitary polyp; (D) Frustule. Scale bar: $300 \mu \mathrm{m}$. 
basal attachment region. Polyp 1 (Figure 2C) larger than polyp 2, although the width of the basal attachment region (bar) was almost the same. Other features similar to the live colony.

\subsection{Frustules}

All three frustules were elongated and rod-like with roughly rounded ends, free of cilia. The anterior and posterior ends were solely recognized by the motion of the frustule in an anterior-posterior direction. The total range in length and width was 540.0-654.5 $\mu \mathrm{m}$ and 101.4-152.7 $\mu \mathrm{m}$ respectively, with nematocysts spread all over, some protruding from the surface. A mucus tube surrounded the distal end in two of the three frustules was observed (Figure 2D). Frustules 2 y 3 budded from colony A (Figure 3B) while frustule 1 (Figure 4A) was found solitary in the aquaria. Frustule leaved a carpet-like path behind it as it slowly moved forwards (Figure 4B).

One frustule was observed "in vivo" budding off from a hydranth and was estimated to grow approximately $130 \mu \mathrm{m}$ in four and a half hours (from 300 to $530 \mu \mathrm{m}$ ) to finally detach overnight at $537 \mu \mathrm{m}$ in length. Five days later a third frustule budded off from the colony overnight, thus we could not distinguish from which hydranth it originated.

\section{4. "In vivo" observations}
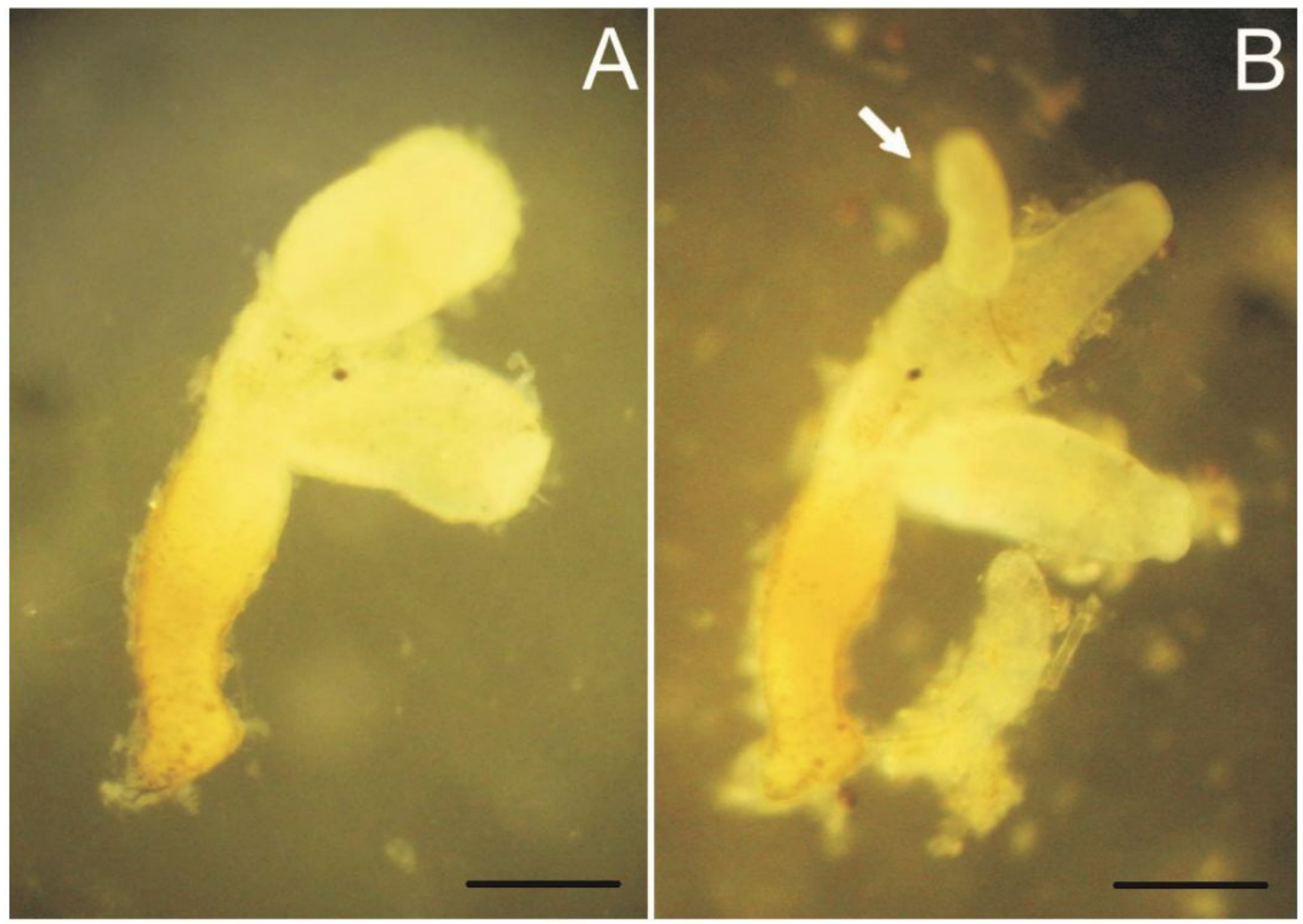

Figure 3. Live Craspedacusta sowerbii colony. (A) with two hydranths $\left(a_{1}-a_{2}\right)$ and (B) with an almost completely liberated frustule (arrow) from hydranth $\mathrm{a}_{1}$. Scale bar: $250 \mu \mathrm{m}$.
Numerous ciliates and copepods were observed grazing on the surface of the hydranths with absence of feeding response. Copepods were paralyzed by the discharge of the nematocysts but never ingested. In contrary, although no movements towards prey were observed, the free-moving polychaete when passing by the polyp's mouth was suddenly immobilized and drawn U-shaped into the gastrovascular cavity. The worm was retained when both ends were approximately equidistant from the center of the hydroid's mouth, and swallowed into the gastrovascular cavity still with the free ends moving (Figure 5A-D). The complete ingestion lasted about 10 minutes. Undigested parts were eliminated, some of which remained attached to the capitulum for several hours or days. The same feeding process was also observed for the smallest solitary polyp (Figure 2C), although lasting almost 30 minutes.

After two days in captivity a bud from the " $a_{1}$ " hydranth was observed, whereby the entire process through the complete release of the frustule lasted less than 14 hours. Four days after budding both hydroids were much more elongated and thinner, reaching almost twice as long as their initial size (a1: $\mathrm{TL}=887 \mu \mathrm{m}, \mathrm{TW}=123 \mu \mathrm{m}$; a2: $\mathrm{TL}=838 \mu \mathrm{m}, \mathrm{TW}=140 \mu \mathrm{m})$, with a well differentiated capitulum. When exposed to light, the distal end of both polyps $\left(\mathrm{a}_{1}\right.$ and $\mathrm{a}_{2}$ ) of colony began to swing slowly from side to side and back and forth. In polyp 1 we observed the capitulum moving to form an angle of almost $90^{\circ}$ in line 


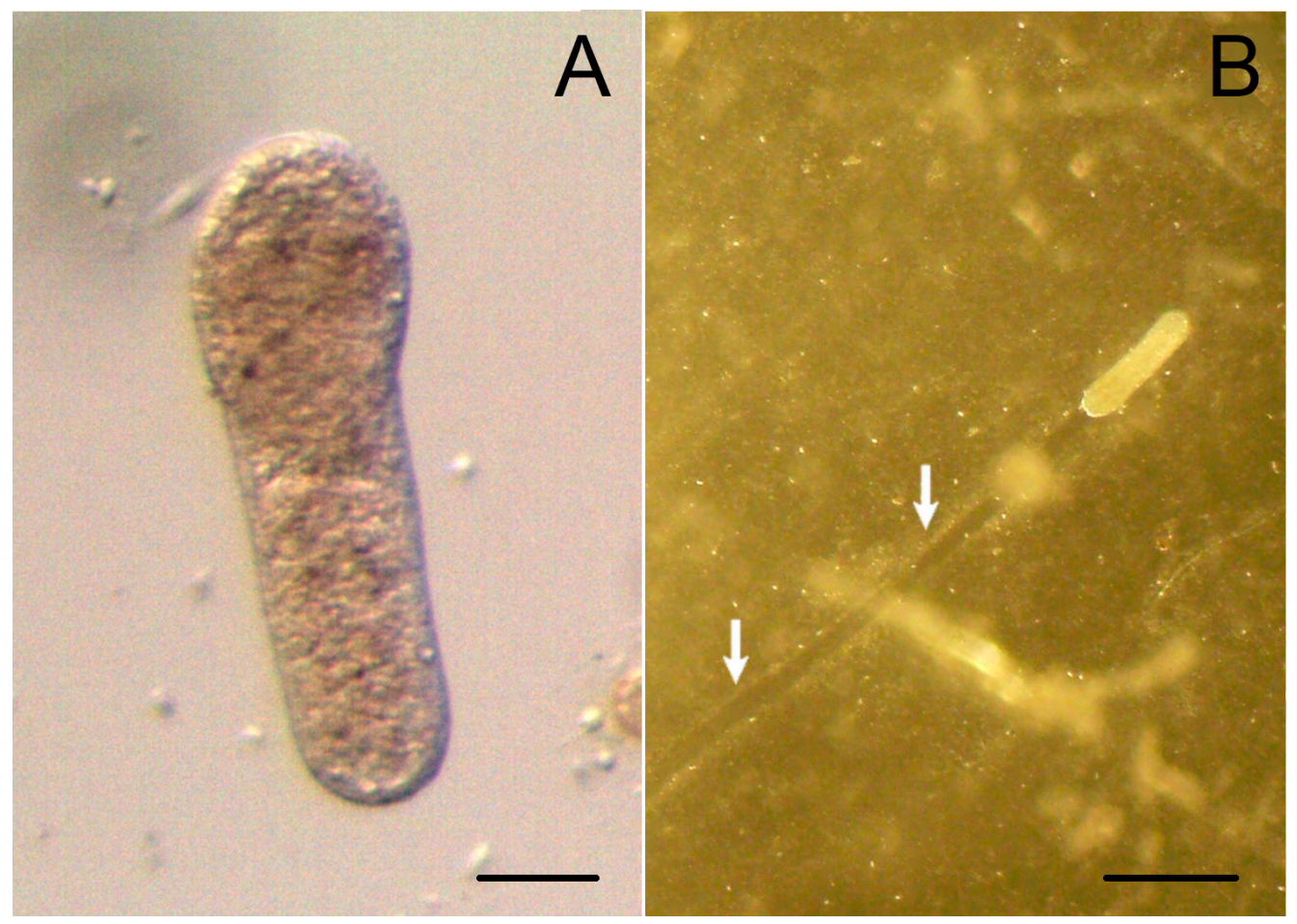

Figure 4. Live Craspedacusta sowerbii frustule. (A) Frustule fixed to the petri dish by one end (thinner) Scale bar: $100 \mu \mathrm{m}$; (B) Frustule creeping leaving a carpet-like mucus path (arrows). Scale bar: $500 \mu \mathrm{m}$.

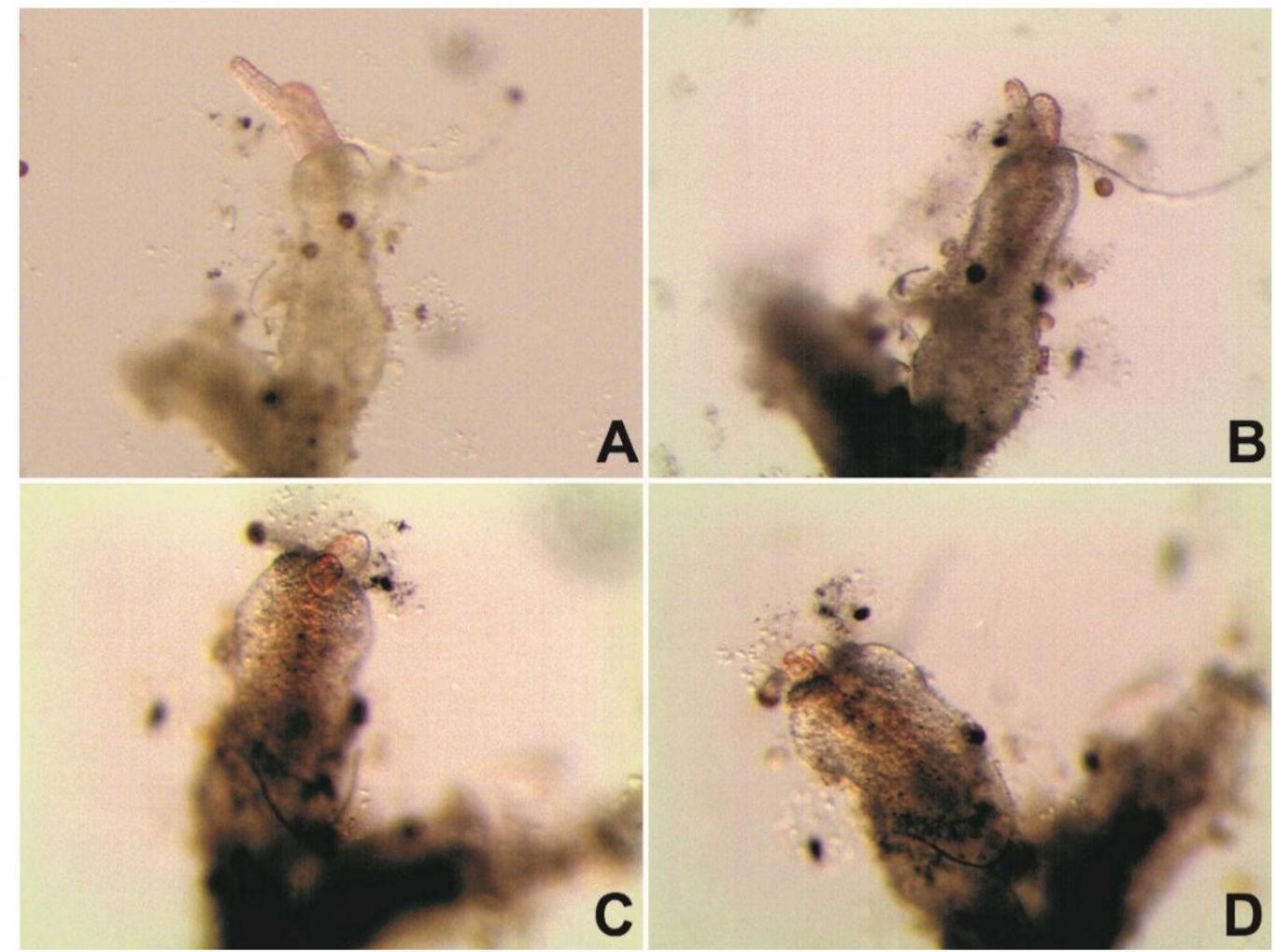

Figure 5. Live Craspedacusta sowerbii colony: ingestion process: (A) worm pulled in U-shaped; (B-C) worm partially ingested; (D) worm almost ingested except to the anterior and posterior ends remaining outside the hydranth (the body of the worm seen by transparency). Scale bar: $250 \mu \mathrm{m}$. 
with the body (over approximately 18 seconds). It remained in this position for a few seconds before straightened again in almost the same time. These movements alternated with slight tilts to the left and right of the capitulum. Both solitary polyps, similar to one of the individuals in the colony $\left(a_{2}\right)$ were observed feeding on worms. Polyp $a_{1}$ had food remains in the oral region and food particles in the upper part of the gastrovascular cavity as seen by transparency, suggesting it had recently eaten.

Particles were stuck together by a cluster of algal cells forming a sort of yellowish theca-like basal portion, to which the hydroids were attached.

\section{Discussion}

The presence of the polyp stage of Craspedacusta sowerbii and its behavior are recorded here for the first time in a natural lagoon, where previously only the medusa stage had been observed (solely in artificial fountains). Records of the distribution of $C$. sowerbii in South America are scarce, which may be due to the geographic distribution of the species as well as the regional scarcity of specialists and the publication of some records in local journals (in portuguese or spanish languages), thus impeding access by an international audience. Although the medusa stage is ephemeral in situ it accounts for almost all species records, as it is more visible and thus more readily detected by non-specialists. Such difficulties have given rise to misinformation on species distribution, such as in a review by Schlenz (1981) where observations of the medusa by Ringuelet (1950) and Vannucci and Tundisi (1962) in Argentina are not included therein, nor in the report of Mañé-Garzón and Carbonell (1971) and Richard (1990) by Silva and Roche (2007).

The identificaction of jellyfish as belonging to C. sowerbii species was confirmed by molecular methods, specifically by PCR amplifying and sequencing a partial 16S ribosomal RNA gene sequence.

\subsection{Polyps}

The colonies studied here are similar in morphology to those previously reported in a natural lake in the US (Payne, 1924; Bushnell and Porter, 1967) and in an aquarium (Matthews, 1963), with a slight difference in the number of individuals. Although Xu and Wang (2009) studied the life cycle of $C$. sowerbyi xinyangensis from zygote to medusa in laboratory cultures, no mention of the number of hydranths per colony has been made.

Our colonies ( $a$ and $b$ ) consisted of two upright individuals joined together by a basal sclerotized region, much larger in colony (a) than in (b), possibly denoting that the former is older. Many authors have observed this theca-like basal portion (Matthews, 1963), also both solitary polyps recovered had a differentiated basal region. Whether the large sclerotized region of colony (a) corresponded to a third hydranth that had previously died but remained fixed would need further observations. Three days after the first frustule had been released from the polyp, the hydrants of the colony became longer and more slender (i.e., from an initial length of $666.5 \mu \mathrm{m}$ to $1152.2 \mu \mathrm{m}$ in hydranth "a,"). The size of hydranth " $b_{1}$ " from colony (b) may reflect elongation of the hydranth upon fixation.

Solitary polyps found in the aquaria are similar to previous descriptions (Payne, 1924; Bushnell and Porter, 1967). Moreover, Xu and Wang (2009) recovered solitary hydranths $450-663 \mu \mathrm{m}$ long from cultures at temperatures of $28-30{ }^{\circ} \mathrm{C}$, stating they were mature individuals. Here, Polyp 2 was within this length range, while Polyp 1 was beyond this range. Given this correspondence in size and the development of a basal attachment region, both polyps may be considered as older individuals. Nonetheless, jellyfish production was not observed during the period of two weeks prior to the death of these individuals. Polyps cultured by Matthews $(1963,1966)$ for over one year also did not produce medusa buds despite control of both temperature and feed. As our polyps had plenty of food available, the fact that there was no medusa budding may have been due to differences in the range of temperatures, as polyps were kept in a refrigerator $\left(8^{\circ} \mathrm{C}\right)$ overnight during the study. Nonetheless, lag times between polyp establishment and medusa detection are potentially extended (Duggan and Eastwood, 2012).

Many food items have been reported in the diet of polyps, including algae, planarians, nematodes, crustacean, small worms, small plankton, insect larvae and water mites (Matthews, 1963; Bushnell and Porter, 1967; Xu and Wang, 2009). It is noteworthy that of all available prey items in the aquaria (ciliates, rotifers, nematodes, copepods, etc.) during the period of observation, hydrants only ingested annelids worms (Aeolosoma sp.).

The feeding mechanism observed both in the colony and the solitary polyp (polyp 2, Figure 1C) were similar, although the process lasted 10 minutes in the former and 30 minutes for the solitary hydranth, likely due to its smaller size. Undigested parts of the prey were egested through the mouth and remained attached to the hydranth for several hours or even days. These observations are similar to those of Matthews (1966) over a shorter period of time. We did not observe cooperative feeding maneuvers of polyps of the colony as described by Bushnell and Porter (1967).

\subsection{Frustules}

Measurement ranges were within those reported by Matthews (1966). Frustule 1 was larger than the other two frustules, bearing a small mucous tube from the distal end that suggested it was older. This frustule was also already in the aquaria before colony budding. "In vivo" budding of the third frustule was observed by evagination of the ectoderm layer, whereby the entire process from the onset of budding until the release of the frustule lasted less than 12 hours. The posterior end bore a perisarc-like transient tube that left a carpeted path, as observed by Matthews (1966), which disappeared from the Petri dish over approximately two hours. Whether there remained a connection with the hydranth could not be observed. Some authors have described "concertina-like" movements of the frustule (Xu and Wang, 2009), or waves of contractility 
(Matthews, 1966). Our observations revealed slight waves of contractile movements of the frustule, similar to creeping, as well as periodically attaching itself by one end and remaining in a semi erect position for a while in the Petri dish, then continuing with creeping movements. During the period of observation larvae moved at the rate of $333 \mu \mathrm{m} \mathrm{s}^{-1}$.

\subsection{Pathways of introduction}

Polyps can encyst as resting bodies (podocysts) and produce resting spherical frustules, which then form polyps when conditions improve. These diapausing stages are drought-resistant, thus facilitating man-mediated dispersal with relocation of aquatic plants, invertebrates, stocked fish and waterfowl (Dumont, 1994; Angradi, 1998). Aerial dispersal, most likely through ornithochory, is also considered to be important, at least on a local scale. According to Parent (1982), Elodea canadensis may have been a vehicle for $C$. sowerbii with a time lag of ca. 50 years. Dispersal by aquatic vegetation is likely one of the main factors. Recent appearance of $C$. sowerbii in Rio Grande do Sul state (Restello et al., 2015; Savaris et al., 2013; Schwarzbold et al., 2010) and our observations, agrees with Silva and Roche (2007) that the distribution area of this species in South America include the La Plata and Amazonas Basins. Although only $9 \%$ of the Uruguayan population lives in the Santa Lucia River Basin (ca. 300,000 inhabitants), it provides drinking water for two million inhabitants of the metropolitan area of Montevideo (Chalar et al., 2013). Pipe obstruction by jellyfishes and polyps has been reported elsewhere (Gershwin 2013; Mant et al., 2011; Purcell et al., 2007), but has not yet been observed in Uruguayan waters. This is the first record of both medusa and polyp stages of C.sowerbii in a natural freshwater lagoon in South America, therefore these observations should contribute to the knowledge on invasive species in the region. High frequency of occurrence between 2008-2012 might suggest that polyps have colonized the lagoon, however further monitoring near the Del Medio Lagoon and elsewhere within the country are needed to establish the mechanism of origin and dispersion, as well as the possible anthropogenic and ecological impacts of C. sowerbii species in Uruguay.

\section{Acknowledgements}

The authors are especially grateful to Dr. G. Genzano, for providing specific bibliography, to Dr. C. Clavijo who helped during the field surveys and to Dr. Christine Lucas, a native English speaker, who kindly revised the text. The authors are also indebted to the two anonymous referees for valuable suggestions which enriched this paper.

\section{References}

ALTSCHUL, S.F., GISH, W., MILLER, W., MYERS, E.W. and LIPMAN, D.J., 1990. Basic local alignment search tool. Journal of
Molecular Biology, vol. 215, no. 3, pp. 403-410. PMid:2231712. http://dx.doi.org/10.1016/S0022-2836(05)80360-2.

ANGRADI, T.R., 1998. Observations of freshwater jellyfish, Craspedacusta sowerbyi Lankester (Trachylina: Petasidae), in a West Virginia Reservoir. Brimleyana: Journal of North Carolina State Museum of Natural Science, vol. 25, pp. 35-42.

BOULENGER, C.L. and FLOWER, W.U., 1928. The Regents Park Medusa Craspedacusta sowerbyi and its identity with $C$. (Microhydra) ryderi. Proceedings of the Zoological Society of London, vol. 66, pp. 1005-1015.

BUSHNELL, J.H. and PORTER, T.W., 1967. The occurrence, habitat, and prey of Craspedacusta sowerbyi (particularly polyp stage) in Michigan. Transactions of the American Microscopical Society, vol. 86, no. 1, pp. 22-27. http://dx.doi.org/10.2307/3224420.

CHALAR, G., DELBENE, L., GONZÁLEZ-BERGONZONI, I. and AROCENA, R., 2013. Fish assemblage changes along a trophic gradient induced by agricultural activities (Santa Lucía, Uruguay). Ecological Indicators, vol. 24, pp. 582-588. http:// dx.doi.org/10.1016/j.ecolind.2012.08.010.

CORDERO, E.H., 1941. Observaciones sobre algunas especies sudamericanas del género Hydra, II. Hydra y Cordylophora en el Uruguay. Anais da Academia Brasileira de Ciencias, vol. 13, pp. 173-183.

CUNNINGHAM, C.W. and BUSS, L.W., 1993. Molecular evidence for multiple episodes of paedomorphosis in the family Hydractiniidae. Bisochestry Systematic Ecology, vol. 21, no. 1, pp. 57-69. http://dx.doi.org/10.1016/0305-1978(93)90009-G.

DIONI, W., 1974. Noticia sobre un raro hidroide de agua dulce de la Argentina y Uruguay, Calpasoma dactyloptera. Physis B, vol. 33 , no. 86 , pp. 147-150.

DUGGAN, I.C. and EASTWOOD, K.R., 2012. Detection and distribution of Craspedacusta sowerbii: observations of medusa are not enough. Aquatic Invasions, vol. 7, no. 2, pp. 271-275. http://dx.doi.org./10.3391/ai.2012.7.2.013

DUMONT, H.J., 1994. The distribution and ecology of the freshand brackish-water medusae of the world. Hydrobiologia, vol. 272, no. 1-3, pp. 1-12. http://dx.doi.org/10.1007/BF00006508.

FIGUEROA, D. and DE LOS RÍOS, P., 2008. First report of Craspedacusta sowerbii (Cnidaria) (Lankester, 1880) for Patagonian waters $\left(38^{\circ} \mathrm{S}\right.$, Chile): a possible presence of invasive species and its potential ecological implications. Brazilian Journal of Biology $=$ Revista Brasileira de Biologia, vol. 70, no. 1, pp. 227-228. http://dx.doi.org/10.1590/S1519-69842010000100032.

FRITZ, G.B., SCHILL, R.O., PFANNKUCHEN, P.M. and BRÜMMER, F., 2007. The freshwater jellyfish Crapedacusta sowerbii Lankester, 1880 (Limnomedusa: Olindiidae) in Germany, with a brief note on its nomenclature. Journal of Limnology, vol. 66, no. 1, pp. 54-59. http://dx.doi.org/10.4081/jlimnol.2007.54.

GERSHWIN, L., 2013. Stung! On jellyfish blooms and the future of the ocean. London: University Chigago Press. 424 p.

JANKOWSKI, T., 2001. The freshwater medusae of the world: a taxonomic and systematic literature study with some remarks on other inland water jellyfish. Hydrobiologia, vol. 462, no. 1/3, pp. 91-113. http://dx.doi.org/10.1023/A:1013126015171.

JANKOWSKI, T., COLLINS, A.G. and CAMPBELL, R., 2008. Global diversity of inland water cnidarians. Hydrobiologia, vol. 595, no. 1, pp. 35-40. http://dx.doi.org/10.1007/s10750-007-9001-9. 
MAÑÉ GARZÓN, F. and CARBONELL, C.S., 1971. Sobre la medusa de agua dulce Craspedacusta sowerbyi Rey-Lank, 1880, en el Uruguay. Boletin de la Sociedad Zoológica del Uruguay, vol. I, pp. 10.

MANT, R.C., MOGGRIDGE, G. and ALDRIDGE, D.C., 2011. Biofouling by bryozoans, Cordylophora and sponges in UK water treatment works. Water Science and Technology, vol. 63, no. 9, pp. 1815-1822. PMid:21902018. http://dx.doi.org/10.2166/ wst.2011.384.

MATTHEWS, D.C., 1963. Freshwater jellyfish Crapedacusta sowerbyi Lankester in Hawaii. Transactions of the American Microscopical Society, vol. 82, no. 1, pp. 18-22. http://dx.doi. org/10.2307/3223816.

MATTHEWS, D.C., 1966. A comparative study of Craspedacusta sowerbyi and Calpasoma dactyloptera life cycles. Pacific Science, vol. 20, pp. 246-259.

PARENT, G.H., 1982. Une page d'histoire des sciences contemporaines: un siecle d'observations sur la meduse d'eau douce Crapedacusta sowerbyi Lank. Bulletin mensuelle de la Société linnéenne, vol. 51, pp. 47-63.

PAYNE, F., 1924. A study of the freshwater medusae, Craspedacusta ryderi. Journal of Morphology, vol. 38, no. 3, pp. 387-430. http:// dx.doi.org/10.1002/jmor.1050380305.

PURCELL, J.E., UYE, S. and LO, W., 2007. Anthropogenic causes of jellyfish blooms and their direct consequences for humans: A review. Marine Ecology Progress Series, vol. 350, pp. 153-174. http://dx.doi.org/10.3354/meps07093.

RESTELLO, R.M., DIDONÉ, M.A. and CARUS, C., 2015. Medusa de água doce: Craspedacusta sowerbii (Lankester, 1880) (Hydrozoa, Limnomedusae) no alto Uruguai do Rio Grande do Sul. Perspectiva, vol. 39, no. 145, pp. 179-182.
RICHARD, E., 1990. Craspedacusta sowerbyi: la curiosa medusa de agua dulce. Subacuática, vol. 2, no. 6, pp. 28-29.

RINGUELET, R.A., 1950. La medusa de agua dulce Craspedacusta sowerbyi Lank. en la Argentina. Museo de La Plata, vol. 15, pp. 135-150.

SAVARIS, M., LAMPERT, S. and HADDAD, M.A., 2013. Craspedacusta cf. sowerbii Lankester, 1880 (Cnidaria: Hydrozoa: Limnomedusae): New record fot the middle plateau region of the state of Rio Grande do Sul, Brazil. Check List, vol. 9, no. 44, pp. 906-908. http://dx.doi.org/10.15560/9.4.906.

SCHLENZ, E., 1981. Coelenterata. In: S.H. HURLBERT, G. RODRIGUEZ and N.D. SANTOS. Aquatic biota of Tropical South America. San Diego: State Univiversity. vol. 2, pp. 96-97.

SCHWARZBOLD, A., VOLKMER-RIBEIRO, C., VASCONCELOS, M.C., SCHNECK, F. and SPONCHIADO, M., 2010. Ocorrência de Craspedacusta sowerbii (Hydrozoa: Limnomedusae) (Lankester, 1880) no reservatório da Usina Hidrelétrica 14 de Julho, Rio Grande do Sul, Brasil. Revista Brasileira de Biociências, vol. 8, no. 3, pp. 305-307.

SILVA, W.M. and ROCHE, K.F., 2007. Occurence of the freswater fellyfish Craspedacusta sowerbii (Lankester, 1880) (Hydrozoa, Limnomedusae) in a calcareous lake in Mato Grosso do Sul, Brazil. Biota Neotropica, vol. 7, no. 1, pp. 173-176. http://dx.doi. org/10.1590/S1676-06032007000100028.

VANNUCCI, M. and TUNDISI, J., 1962. Las medusas existentes en los Museos de La Plata y Buenos Aires. Comisión del Museo Argentino de Ciencias Naturales: Bernardino Rivadavia, vol. 3, pp. 203-215.

XU, S. and WANG, D., 2009. Life cycle of Craspedacusta sowerbii xinyangensis. Current Zoology, vol. 55, no. 3, pp. 227-234. 